\title{
Correction to: Abstracts
}

\section{9th European Congress of Pathology}

\section{S. Lopes Petronilho ${ }^{1} \cdot$ D. Montezuma ${ }^{1} \cdot$ R. Vieira ${ }^{1} \cdot$ A. L. Cunha ${ }^{1} \cdot$ R. Henrique ${ }^{1}$. C. Bartosch ${ }^{1}$}

Published online: 14 November 2017

(C) Springer-Verlag GmbH Deutschland 2017

Correction to: Virchows Archiv (2017) 471(Suppl 1):S1S352

https://doi.org/10.1007/s00428-017-2205-0

In Oral Free Paper Sessions, the first-author name was missing from the authorship group originally listed for Abstract OFP04-012 (page S14), entitled "Differentiating primary pulmonary squamous cell carcinoma from squamous cell carcinoma of the cervix metastatic to the lung: Histological and immunohistochemistry study". The correct authorship group is shown above.

The online version of the original article can be found at http://dx.doi.org/ 10.1007/s00428-017-2205-0

S. Lopes Petronilho s.petronilho@gmail.com

1 IPO-Porto, Pathology, Portugal 